\title{
Digital Literacy in ESL Classroom
}

\author{
Oktavian Mantiri ${ }^{1{ }^{1 *},}$, Garth K. Hibbert ${ }^{2}$, Jeanette Jacobs ${ }^{1}$ \\ ${ }^{1}$ Faculty of Education, Universitas Klabat, Airmadidi, Indonesia \\ ${ }^{2}$ Faculty of Education and Psychology, Asia-Pacific International University, Saraburi, Thailand
}

Copyright@2019 by authors, all rights reserved. Authors agree that this article remains permanently open access under the terms of the Creative Commons Attribution License 4.0 International License

\begin{abstract}
Literacy is more than the ability to decode words and digital literacy is more than the ability to use a computer. This paper will attempt to define digital literacy and the benefits it provides to both the English language learner (ELL) and the English language instructor. It will also explore some of the misconceptions surrounding digital literacy and try to show that there is a need for basic training in this area for all language educators. Schools have taken the first step by providing access to computer technology in the classrooms; however, most have short-changed students in the development of digital skills.
\end{abstract}

Keywords Digital Literacy, English as Second Language, English Language Learner, Technology in Language Education, Learn English Websites

\section{Introduction}

Traditionally, the foundation for learning a second language has been rooted in acquiring writing, reading, speaking, and listening skills, mainly from textbooks and role plays. This current generation is exposed to all kinds of digital technology that allows them to communicate in ways that incorporate these four language skills while creating new skills. As educators, we need to evaluate the way we view and measure literacy.

In his book, Grown Up Digital: How the Net Generation is Changing Your World, Don Tapscott [1] implies that in order to become progressive educators around the world, there is a need to change the pedagogy to fit the demands of this fast-paced world, in which the ability to think and learn and find out things is more important than mastering a body of knowledge that has been regurgitated over and over. He goes on to explain that in our society today, it is not what you know that really counts. Instead, it is how you navigate in the digital world and how you use the information you discover. This is the new style of learning (p. 134). So how to create a critical pedagogy for the digital age? The researcher will attempt to link the concept of digital literacy with its practical use in the ESL classroom

\section{What is Digital Literacy?}

Some people are under the misconception that digital literacy means the ability to use a computer and so by putting computer technology in the classrooms, we will have digitally literate students. However, one does not automatically lead to the other. According to the NYC Department of Education [2], to be digitally literate is more than knowing how to use a smart phone or accessing music videos on YouTube. It means having the knowledge and ability to use a wide range of technology tools for a variety of purposes. A digitally literate person can use technology strategically to discover and evaluate information, connect and collaborate with others, produce and share original content, and use the Internet and technology tools to achieve many academic, professional, and personal goals.

In his ebook, The Essential Elements of Digital Literacies, Doug Belshaw [3] states that the term digital literacy is an ambiguous concept because it is hard to define and measure. Instead, he proposes that it is made up of several critical elements. These eight elements in figure 1 were compiled from his research using key terms from various definitions of digital literacy. 


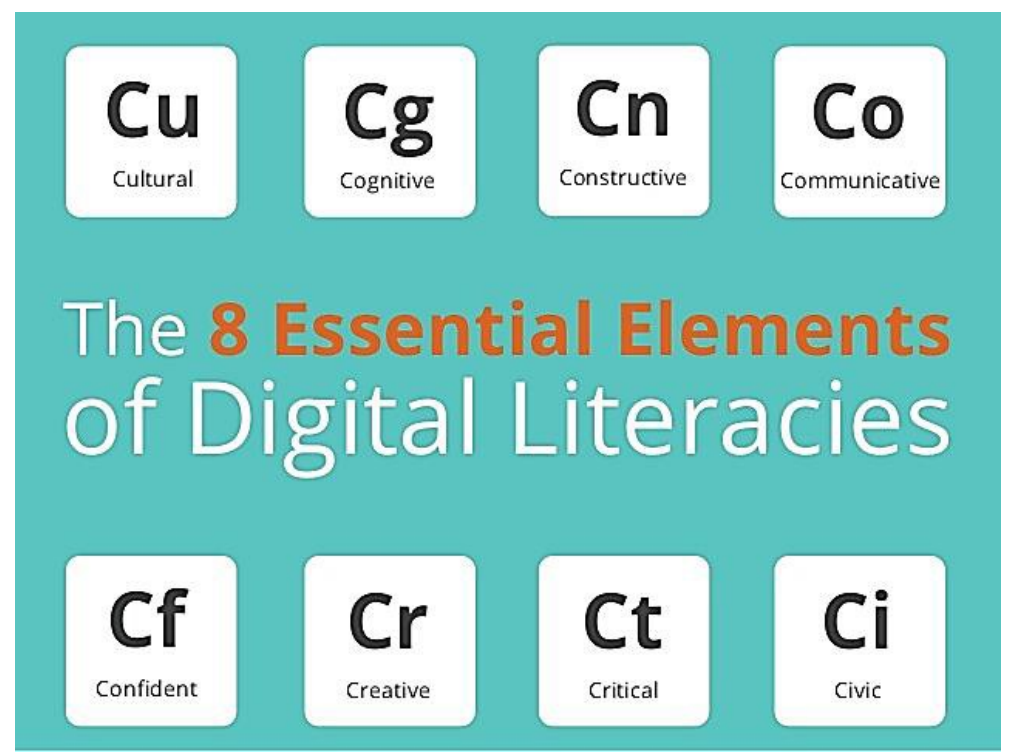

Figure 1. The Eight Cs of Digital Literacies [4]

None of these eight elements is new to educators. Broens, Guldbaek \& Vinkel [5] also emphasize that students need to learn how to learn, which means they need to be creative, experiment, communicate, disseminate, take responsibility, work together, exchange and respectfully discuss opinions. So the question is, how do we then incorporate them into our ESL curriculums so that our students become cultural, cognitive, constructive, communicative, confident, creative, critical, and civic learners?

One answer to this question is to gamify learning. Students respond well to this because it is fun; they can earn points while proceeding at their own pace and competing against themselves. An application such as Duolingo provides the gaming aspects mentioned above, but offers much more. With this one program, students get the opportunity to construct knowledge, to explore what they are really interested in learning. Communicating with other learners via discussion boards gives them a variety of answers and perspectives. They must then evaluate and synthesize all this information and choose what best fits their needs. Through this process, students are also making cultural connections with fellow posters, which will require a certain level of confidence. Students can then use the information gained to create products that serve a civic purpose. This takes learning beyond the classroom and beyond regurgitating information. Apps like Duolingo are available on computers, smart phones, and tablets. Students control how and where they use these apps.

FluentU provides similar benefits to Duolingo, but does not quite provide the gaming qualities. Instead, it utilizes closed captioned music videos of popular songs to facilitate the learning of language. Vocabulary is learned through brief animated video clips. Users customize content to fit their needs and lifestyles. Users get feedback through quizzes and other type of content review. Feedback is also provided through weekly emails informing students of new content as well as different and interesting ways to learn and practice. Again, students must evaluate what best fits their needs. Teachers meet the creative, communication and constructive elements of Belshaw's Digital Literacies by having students create and annotate videos using songs they like or creating their own songs and music. Students can create individually, as a group or as a class. These videos can then be shared will all kinds of people across all kinds of platforms, YouTube, Facebook, Twitter, etc. In this system, the four learning skills referenced earlier are incorporated to provide a learning platform that speaks to a variety of learning styles.

\section{Overcoming Challenges to Digital Literacy}

According to Madden, Ford, Miller, and Levy [6], while school access to the Internet is almost $100 \%$ in the United States, in some countries it is much less frequently integrated into meaningful learning opportunities. With this in mind, it is crucial to be aware of some of the challenges faced by educators who would like to see their students excel in this area. In her article Preparing ELLs to be 21st-Century Learners, Kristina Robertson [7] identifies five challenges for ESL teachers who want to have their students become more proficient in using technology.

The first challenge is language. Students are expected to master technology in a language that they are not yet comfortable or familiar with. Computer technology comes with a set of jargon that is not usually in a typical English class for beginners. To overcome this, instructors need to make sure that students understand the new vocabulary before any demonstration or hands on participation with the software. Teachers can also provide handouts which use many pictures and symbols to help students navigate 
the lesson. Using print screens can also help students who need clarification about the assignment or to check their own work for accuracy.

The second challenge is limited access. Many second language learners are also recent immigrants and sometimes these families find themselves in situations where they are struggling economically. There might not be enough money to provide access to technology at home. It is very difficult for these students to reinforce what they are learning in the classroom. One solution is to make students aware of any technology available to them at school or in the community like a public library. Another solution is to seek administration's approval for them to use the technology outside of regular school hours.

The third challenge is different levels of experience. Any educator can attest that students do not all learn at the same pace. Differentiated learning has been the solution to this dilemma. Fortunately, one of the advantages of digital technology is its ability to adapt to the needs of students. One of the writer's favorite programs is found at Duolingo.com which is a free online language learning website. The activities incorporate reading, writing, listening, and speaking skills in each lesson and are divided into categories. Each student can do the activities without any time constraint. For more advanced learners, they can test out of a category and move on to something more challenging.

The fourth challenge is school infrastructure. This challenge is the hardest to overcome because a lack of infrastructure usually means a lack of funds available to school administrators. If the school has the money, but does not see the need, then the teachers need to convince the school administration by reporting on the vast amount of research that has been done in this area. If there is no money, but a willingness to support the program, then the school needs to get the parents and the community involved by having fundraisers. They are also many organizations which are willing to fund technology in school such as the Bill and Melinda Gates Foundation that can be appealed to for aid.

The final challenge is keeping up. We live in a world that is constantly changing and where technology becomes obsolete almost as quickly as it becomes available. However, the same way that a doctor keeps up with the latest medical breakthroughs because the health of the patient is very important, teachers must also keep up with the latest, affordable technology that has been proven to help students learn because students' success is also important. They should not forget that they are nurturing tomorrow's doctors, teachers, tour operators, etc. Teachers should also not forget that students are often the best sources for discovering and utilizing technology. If planned intentionally, teachers can challenge students to brainstorm creative ways to use new technology in the ESL classroom. When it comes to the impact of change, John F. Kennedy [8], the $35^{\text {th }}$ president of the United States, said it best, "For time and the world do not stand still. Change is the law of life. And those who look only to the past or the present are certain to miss the future”.

\section{Digital Literacy in the ESL Classroom}

One of the best ways to create digital literacy is through the use of Information and Communications technology (ICT). According to the website, ICT For Diversity [9], carefully structured computer programs are able to offer an alternative approach which builds on the successful features of traditional teaching methods. In other words, teachers can integrate technology into their lesson plans in ways that add value. ICT For Diversity suggests three benefits for both students and teachers. First, the technology can present text in a very highly structured way and can pace the introduction of new concepts and skills depending on the progress the pupil makes through the program. Second, they can provide aural feedback to the pupil in a timely fashion. Thirdly, the technology will continue to work patiently for as long as the pupil is prepared to keep trying.

One of the writer's friends recently shared a story about one of his coworkers, who is being recognized by the NYC Education Department for his success in improving the digital literacy of his students. With his permission [10], here is an excerpt from the letter written by the principal of his school:

Joseph Videtto, Occupational Therapist and the Technology Single Point of Contact (SPOC) at PS in Brooklyn, has found that by incorporating technology into his lessons, he is able to both increase student participation and improve their functional skills... He helps teachers' select educational websites that can be incorporated into their lessons and used the SMART Boards during class time. He also hosts professional development sessions on using technology tools to tailor activities to each student's individual needs.

The ability to provide student-centered or student-directed learning is one of the reason's Joseph was able to improve the digital literacy at this school. Students who are directly engaged in the learning process, develop important learning skills, such as critical thinking, problem solving, team building, and become effective communicators. So with the use of digital literacy software, educators can give students more personalized learning allowing them to work at their own pace and take charge of their own learning.

In the article How Digital Literacy Tools Help English Language Learners Succeed, the Center For Digital Education (CFDE) [11] indicates that there are some key features about digital literacy software that makes learning easier, more fun, and as a result, students are more likely to be intrinsically motivated. One key feature is technology-enhanced vocabulary acquisition. 
Learning vocabulary is key to mastering a language. The WordDive Team [12] identifies three key reasons why increasing and evolving vocabulary is necessary for foreign language learners. They propose that vocabulary is the key to communication, strong vocabulary allows [learners] to develop other skills, and the more words [they] know, the more [they] will learn. Digital programs can help ELLs acquire essential new words in ways that are more engaging and effective than traditional printed flashcards according to CFDE [11].

Another key feature, claimed DFCE [11], is that instruction is guided by multimedia. Some examples of this include text-to-speech capabilities which reinforce proper pronunciation and fluency; digitally annotating within the texts allows students to make notes for later review or questions they can later submit the teacher for clarification; and multimedia features like images, sounds and videos can be used to explain important concepts that are too complex for a short definition.

A third key concept that is a great selling point is the customization capabilities. Digital literacy programs can assist teachers with personalization and differentiation in the classroom by offering personalized tasks and materials that are matched to each student's abilities, said CFDE [11]. This allows students to learn without the frustration of failing to complete a task because it is too difficult or racing through the material because it is too basic for their level of comprehension.

So what are some practical ways to create or improve digital literacy in our students? The website Purposeful Technology-Constructing Meaning in 21st Century Schools [13] suggests some activities to promote higher order thinking and construction of meaning in the digital literacy environment. Here are a few that can work in most ESL classrooms:

- Use an interactive whiteboard as often as possible to design and deliver lessons.

- Engage in email/video chat exchanges with students from other countries. (This is very useful to build student's confidence and provide real world usage of the English language).

- Utilize storytelling media to allow students to create and publish stories.

- Set up a blog site/Facebook page and post weekly discussion questions for students to respond to. Encourage them to respond to each other too!

- Engage students in discussions about how and why various media work well to show case learning and why others do not. Thinking critically about the medium use to present a message is just as important as the message itself.

\section{Conclusions}

Despite the misconceptions about the relationship between digital literacy and computer technology, and the challenges faced by many educators trying to develop digitally literate students, as ESL teachers it is our duty to make digital literacy a focal point of our teaching plans. Computer technology has made our lives easier by allowing students to submit their assignments via email or by using ebooks instead of paper textbooks, but we have only scratched the surface. Let us take advantage of the available technology that helps our students think critically, motivates them to take charge of their learning and build bigger vocabularies with words that hold contextual meaning for them, and allows them to learn at their own pace through differentiated learning. We will know we have succeeded when students willingly communicate in the English language at every given opportunity outside of the classroom environment.

Recommendations for teachers are as follow:

- $\quad$ Be adaptable towards technology use;

- Be open-minded and willing to learn from the students, the digital natives;

- $\quad$ Be up-to-date with technological advancements.

\section{REFERENCES}

[1] Tapscott, D. (2008). Grown up digital: How the net generation is changing your world. McGraw-Hill. Retrieved on January 8, 2015 fromhttp://bookzz.org/book/675566/04 ff73

[2] NYC Department of Education. (2015). Enhancing digital literacy. Retrieved on April 16, 2015 from http://schools.n yc.gov/community/innovation/ConnectedFoundations/ED L/default.htm

[3] Belshaw, D. (2011). The essential elements of digital literacies. Retrieved on April 16, 2015 fromhttp://www.sli deshare.net/dajbelshaw/the-essential-elements-of-digital-lit eracies.

[4] Belshaw, D. (2011). The 8 Essential Elements of Digital Literacies. Retrieved from https://i0.wp.com/lynhilt.com/wp -content/uploads/2013/02/8essentialelementsofdigitalliteracy .jpg

[5] Broens, M. G., Guldbaek, J., \& Vinkel, H. B. (2011). Transforming pedagogical ethos into an effective learning environment. Retrieved on April 16, 2015 from http://www.oecd.org/edu/innovation-education/centreforeff ectivelearningenvironmentscele/47211923.pdf

[6] Madden, A., Ford, N., Miller, D., \& Levy, P. (2005). Using the internet in teaching: The views of practitioners (A survey of the views of secondary school teachers in Sheffield, UK). British Journal of Educational Technology, 36(2), 255-280. Retrieved on April 19, 2015 from https://www.deepdyve.com/lp/wiley/using-the-internet-in-t eaching-the-views-of-practitioners-a-survey-of-WNaRcyt $\mathrm{NgH} / 25$

[7] Robertson, K. (2008). Preparing ELLs to be 21st-century learners. Retrieved on April 17, 2015 from http://www.col 
orincolorado.org/article/21431/

[8] Kennedy, J. F. (1963). Address in the assembly hall at the Paulskirche in Frankfurt. Online by Gerhard Peters and John T. Woolley, The American Presidency Project. Retrieved on April 19, 2015 from http://www.presidency.u csb.edu/ws/?pid=9303.

[9] ICT For Diversity. (2012). Does ICT benefit diverse learners? Retrieved on April 20, 2015 from https://ictfordi versity.wordpress.com/english-as-a-second-language-esl/

[10] Videtto J., January 20, 2015. Personal letter communication.

[11] Center For Digital Education. (2014). How digital literacy tools help English language learners succeed. Retrieved on April 16, 2015 from http://www.centerdigitaled.com/paper/ How-Digital-Literacy-Tools-Help-English-Language-Lear ners-Succeed.html?promo_code=Featured\%20Papers\%20 Module

[12] WordDive Team. (2013). Words will get you far: Why is vocabulary acquisition so important in second and foreign language learning? Retrieved on April 19, 2015 from http://www.worddive.com/blog/words-will-get-you-far-wh $\mathrm{y}$-is-vocabulary-acquisition-so-important-in-second-and-fo reign-language-learning/

[13] Purposeful Technology-Constructing Meaning in 21st Century Schools. (n.d.). How can we embed digital literacy into the classroom? Retrieved on April 17, 2015 from http://purposefultechnology.weebly.com/how-can-we-emb ed-digital-literacy-in-the-classroom.html 